\title{
Experimental Norms: Power-Knowledge, Bare Life and Medical Trials
}

\author{
Edwin Bikundo \\ Griffith University, Australia
}

\begin{abstract}
Humans experimenting on other humans sits precisely at the junction of law, technology and the humanities, synthesising descriptive, normative and creative elements in relation to reality. Experiments describe reality, normalise shared conceptions of reality as well as create their own reality. Human experiments consequently inflect both 'norm' and 'humanity' as a pattern or as a model, or even a standard to be met or fulfilled. Experiments abound in Italian philosopher Giorgio Agamben's body of work, including where he engages with the capacity for development of Michel Foucault's opus. This is particularly so when Agamben explicitly addresses questions and criticisms surrounding his own methodology.
\end{abstract}

Keywords: Giorgio Agamben; experiments; the Faustian Pact; law; ethics; power; knowledge.

\section{Introduction}

This paper starts by locating human experimentation at the intersection of the power-knowledge axis, as articulated in Giorgio Agamben's elaboration of Michel Foucault's insight regarding when and where humans are both examining subjects and examined objects in the production of knowledge. According to Foucault, this produces a context in which 'science has become institutionalised as a power through a university system and through its own constricting apparatus of laboratories and experiments.' ${ }^{1}$ The paper next identifies how discrimination, particularly on the basis of race and class, has played a key role in the selection of human experimental subjects for illegal experimentation. It then demonstrates that the justifications for experimentation along the Foucaldian power-knowledge axis are often politically theodicean in justifying the evil effects and intent of power by the promise of the knowledge to be gained. This is done while reading the Faustian pact narrative as already ubiquitous in human experimentation, and by illustrating that both textually and thematically. The paper then argues that experiments on humans describe reality, normalise shared conceptions of reality and create reality by inflecting both 'humanity' and 'norm' simultaneously as a pattern and as a model, and even a standard to be fulfilled. It concludes that if experiments were solely based within a scientific paradigm without any elements of political power they would not be so legally and politically charged with discriminatory practices. This is further confirmation, if needed, that human experimentation is always structured along the power-knowledge axis, with humans divided into examining subjects and examined objects.

\section{Experiments as Enacting Power-Knowledge}

Human medical, biological and scientific experimentation on other humans is profoundly haunted by moral ambiguity. For instance, although prominent Nazi doctor Eduard Pernkopf's book of anatomy-which was based on unlawful experimentation on concentration camp inmates - is still in current use by surgeons, despite being out of print and commanding thousands of pounds sterling in price. ${ }^{2}$ The scientific utility of the knowledge gleaned through illegal and unethical experimentation might well be demonstrable. Yet, it nonetheless runs the real risk of utterly dehumanising its subjects due to the absolute power that is wielded over them. Indeed, Holocaust survivor Olga Lengyel observed first-hand that 'since they [Nazi doctors] were free to do whatever they wished, they decided to experiment on these [human guinea pigs at Auschwitz-Birkenau] people. ${ }^{3}$ This is to

\footnotetext{
${ }^{1}$ Foucault, Philosophy Culture, 107.

2 Baker, "Nazi Book."

${ }^{3}$ Lengyel, Five Chimneys, 185.
}

Except where otherwise noted, content in this journal is licensed under a Creative Commons Attribution 4.0 International Licence. As an open access journal, articles are free to use with proper attribution. ISSN: 2652-4074 (Online) 
say human experimentation sits right at the junction of Michel Foucault's inseparable power-knowledge dyad and practices of normalisation. ${ }^{4}$ As will become increasingly clear, these two related but competing axes invariably coincide in unlawful experimentation at international criminal law, whose processes are somewhat at a loss to recognise this, let alone sever that link. Xavier Aurey, for one, has noted law's failure 'to address one of the most difficult issues in clinical trials and human experimentation: the almost unavoidable context of exploitation of any situation where a person is used as an object for the good of others.' 5

As the Oxford English Dictionary will attest, trials and experiments overlap in sense and meaning. In both experiment and trial, in very general terms, the logical relation between means and ends seems to be crucial. Not only does an 'experiment' etymologically derive from 'try,' but also it denotes trying new ideas or testing a hypothesis. Its horizon of meaning includes a tentative procedure or an unproven method, or an uncertain course of action embarked upon to confirm whether (or not) it will suit a specified purpose. Thus, it is an action, or indeed an operation, that is undertaken strictly to discover something unknown or to test a hypothesis, or even to establish or perhaps illustrate something already known.

Likewise, 'trial' as can be seen in 'trial and error' or clinical trial refers to an 'experiment' as well as to an action, investigation, method or treatment that is adopted to ascertain a result by means of experiential knowledge (akin with an archaic definition of 'experimental' to mean based on experience as distinguished from authority or conjecture). Of course, it also refers to the examination and determination of a cause by a judicial tribunal generally or, with respect to criminal law specifically, to the determination of guilt or innocence (strictly speaking, innocence is never in issue in a criminal trial because of the rebuttable presumption of innocence) of an accused person by the court. Fairly appositely, the first chapter of Agamben's Karman (2018), 'Causa and Culpa,' opens with the observation that both causa (as either cause or case or both) and culpa (as culpability or imputability) 'lack an etymology.' ${ }^{6}$ Indeed, 'they are not juridical concepts in the strict sense, but instead mark ... the point at which a certain act or fact enters into the sphere of law. ${ }^{7}$ Following from the above identification of experimentation as being as much to do with the amenability of the experimental subjects to the will of the experimenter (as opposed to, say, solely the inherent scientific value of the inquiry), this paper quite by accident discovered that the verb 'try' links medical trials, legal trials and political trials. This link yields three distinct but related meanings of the word 'experiment' in a way that is reliant on the literary trope of the pun, concerning: ${ }^{8}$

1. medical trials experimenting on prisoners

2. the concentration camps as a political experiment in totalitarianism

3. the Nuremberg trials as an experiment in international criminal justice.

Consequently, this paper argues that unlawful human experimentation is not only about extending the boundaries of human knowledge by expanding the scope of objective empirical science, but also can be sullied over by the expression of political power over human life stripped bare of all legal and political protections. The illegal and illegitimate willingness for anyone (not just totalitarian regimes) to do whatever one wishes to another human being and then deciding upon experimentation, which is then prosecutable as unlawful, is in this way the core problem addressed in this paper.

Agamben acknowledges his conceptual and methodological indebtedness to Foucault along with Walter Benjamin:

The three essays published here contain my observations on three specific questions regarding method: the concept of the paradigm, the theory of signatures, and the relation between history and archaeology. If these observations appear to be investigations on the method of Michel Foucault, a scholar from whom I have learned a great deal in recent years, this is because one of the methodological principles not discussed in the book - and which I owe to Walter Benjamin - is that doctrine may legitimately be exposed only in the form of interpretation. ${ }^{9}$

When Foucault was asked, 'your analysis of the relations between knowledge and power takes place in the area of the human sciences. It does not concern the exact sciences, does it?’ He responded affirmatively:

Oh no, not at all! I would not make such a claim for myself. ... But what seems to me to be more interesting to analyze is how science, in Europe, has become institutionalized as a power. It is not enough to say that science is a set of procedures by which propositions may be falsified, errors demonstrated, myths demystified, etc. Science also exercises power: it is, literally, a power

\footnotetext{
${ }^{4}$ Foucault, Discipline and Punish, 184-185.

5 Aurey, "Nuremberg Doctors' Trial," 1054.

${ }^{6}$ Agamben, Karman, 1.

${ }^{7}$ Agamben, Karman, 5.

8 'Humanity' too is often punned in international criminal law. See 'to pun is to treat homonyms as synonyms,' Redfern, Puns, 17.

${ }^{9}$ Agamben, The Signature of All Things, 7.
} 
that forces you to say certain things, if you are not to be disqualified not only as being wrong, but, more seriously than that, as being a charlatan. ${ }^{10}$

Not only has Agamben's propounding of his central thesis of 'bare life' as life denuded of all legal protection and, thereby, amenable to anything ${ }^{11}$ been especially useful in this regard, but also his less prominent work on experiments has been very instructive for the project's aims. Therefore, what roles do experiments play in Agamben's work and why would it matter? 'Experiment' here means the controlled and deliberate verification of experience through repetition to produce knowledge (i.e., transforming individual subjective experience into general objective knowledge). The development of experimentation can be related to the problem of the loss of experience as a symptom of modern humanity's loss of experience. As will be shown, Agamben argues this in Infancy and History (1993), which owes a great deal to Walter Benjamin. However, what is at stake here is law's judgement over science and technology in the form of illegal experimentation. To begin, in What Is Real (2018) Agamben makes the counterintuitive point that "what is at stake in the experiment is not so much the knowledge of that system as, first and foremost, the modification it undergoes due to the measuring instruments. ${ }^{12}$ It is worth mentioning that Agamben is speaking here of the new paradigm of experimentation provided by quantum physics. Further, not only is there that unavoidable estrangement between the state of what is observed through those instruments and that state in itself, but also that currently 'science no longer trie[s] to know reality but—like the statistics of social sciences—only [to] intervene in it in order to govern it. ${ }^{13}$ Illuminatingly, in Infancy and History Agamben said that:

the scientific verification of experience which is enacted in the experiment-permitting sensory impressions to be deduced with the exactitude of quantitative determinations and, therefore, the prediction of future impressions - responds to this loss of certainty [here embodied in Descartes' deceitful demon] by displacing experience as far as possible outside the individual: on to instruments and numbers. ${ }^{14}$

In Potentialities (1999) Agamben is of the view that 'one could thus say of philosophy what Milner says of linguistics-that it is "an experimental science without an observation post," ... a science that has the example as its proper mode of experimentation. ${ }^{15}$ In this respect, it is worth recalling that example (paradigm) is also Agamben's fundamental mode of experimentation. ${ }^{16}$ In Means without End (2000) politics too is not excluded from experimentation for Agamben in that 'contemporary politics is this devastating experiment that disarticulates and empties institutions and beliefs, ideologies and religions, identities and communities all throughout the planet, so as then to rehash and reinstate their definitively nullified form. ${ }^{17}$ This point regarding politics being run as an experiment is present too in The Open (2003), in which Agamben suggests that:

perhaps not only theology and philosophy but also politics, ethics, and jurisprudence are drawn and suspended in the difference between man and animal. The cognitive experiment at issue in this difference ultimately concerns the nature of man-or, more precisely, the production and definition of this nature. ${ }^{18}$

In The Use of Bodies (2016) Agamben notes, among other things, that for Foucault sadomasochism was 'an experiment in fluidifying power relations. ${ }^{19}$ Foucault himself stated that his works such as Madness and Civilization (1961), The Birth of the Clinic (1963) and The Order of Things (1966) 'should be read as an ensemble of descriptive experiments still in basic outline. ${ }^{20}$ Further:

the critical ontology of ourselves has to be considered not, certainly, as a theory, a doctrine, nor even as a permanent body of knowledge that is accumulating; it has to be conceived as an attitude, an ethos, a philosophical life in which the critique of what we are is at one and the same time the historical analysis of the limits that are imposed on us and an experiment with the possibility of going beyond them. ${ }^{21}$

\footnotetext{
${ }^{10}$ Foucault, Philosophy Culture, 106-107.

${ }^{11}$ Agamben, Homo Sacer, 159.

${ }^{12}$ Agamben, What Is Real, 13.

${ }^{13}$ Agamben, What Is Real, 13.

${ }^{14}$ Agamben, Infancy and History, 17.

${ }^{15}$ Agamben, Potentialities, 68.

16 Kotsko, Agamben's Philosophical Trajectory, 177.

${ }^{17}$ Agamben, Means without End, 109.

${ }^{18}$ Agamben, The Open, 22.

${ }^{19}$ Agamben, The Use of Bodies, 96-97, 102, 107.

${ }^{20}$ Foucault, Aesthetics, 310.

${ }^{21}$ Foucault, The Politics of Truth, 118.
} 
Thus, ethics is - for Foucault and more than likely, therefore, for Agamben too - an experiment, which involves a certain process of subjectification. In Kingdom and Glory (2011) Agamben highlights the surprising appearance in Linneaus (given that 'we are accustomed to thinking of [him] as the founder of modern scientific taxonomy') of a familiarly theological paradigm where providence is presented through the presentation of thought experiments in the 1740 s and then in 1760 'in such a way that an apparent evil in reality agrees with the general good.'22 Troublingly, in Remnants of Auschwitz (1999) Agamben notes that 'before being a death camp, Auschwitz is the site of an experiment that remains unthought today, an experiment beyond life and death in which the Jew is transformed into a Muselmann and the human being into a nonhuman. ${ }^{23}$ Therefore, the centrality of the experiment to Agamben's work can hardly be overstated. Central for the present project, however, is where Agamben addresses medical experimentation in concentration and extermination camps in at least two places. He makes the point that not only did medical experiments occur in those camps, but also that those camps in themselves were in all probability a political experiment. ${ }^{24}$ Further to the point, Agamben pays substantial attention to human experimentation in the chapter titled 'VP' (abbreviating the German for 'Versuchspersonen, human guinea pigs' ${ }^{25}$ ) in Homo Sacer (1998) to pose the controversial question regarding experiments on people sentenced to death in the United States:

If it was theoretically comprehensible that such experiments would not raise ethical problems for officials and researchers inside a totalitarian regime that moved in an openly biopolitical horizon, how could experiments that were, in a certain sense, analogous have been conducted in a democratic country? ${ }^{26}$

His suggested answer is equally if not more controversial:

The only possible answer is that in both contexts the particular status of the VPs was decisive; they were persons sentenced to death or detained in a camp, the entry into which meant the definitive exclusion from the political community. Precisely because they were lacking almost all the rights and expectations that we customarily attribute to human existence, and yet were still biologically alive, they came to be situated in a limit zone between life and death, inside and outside, in which they were no longer anything but bare life. Those who are sentenced to death and those who dwelt in the camps are thus in some way unconsciously assimilated to homines sacres, to a life that may be killed without the commission of homicide. ${ }^{27}$

In the Creation and Anarchy chapter 'What Is a Command?' Agamben traces two linguistic aspects relevant to understanding 'the real'. ${ }^{28}$ The first is the assertion, which is in the indicative mood, and the second is the commandment, which is in the imperative mood. ${ }^{29}$ One refers to what 'is' or exists, and the other refers to what will 'be' or will exist respectively. One belongs to science and philosophy, and the other to law, religion and magic. ${ }^{30}$ Agamben makes this same point this time with a Foucualdian inflection in Sacrament of Language (2011):

In this perspective the sharp distinction between assertorial oaths and promissory oaths corresponds to the loss of the experience of speech that is in question in the oath. This is neither an assertion nor a promise but something that, taking up a Foucauldian term, we can call a 'veridiction,' which has as the sole criterion of its performative efficacy its relationship to the subject who pronounces it. ${ }^{31}$

Agamben goes on to note that:

in this sense the opposition between faith and religion, so important in modern culture, in reality corresponds point by point to the opposition between two co-originary characteristics of the logos, which are veridiction (from which law and positive religion proceed) and assertion (from which logic and science derive). ${ }^{32}$

What is more for Agamben, 'to this linguistic partition there corresponds the partition of the real into two correlated but distinct spheres: the first ontology in fact defines and governs the sphere of philosophy and science; the second, that of law, religion, and magic.' 33 The imperative defines the verbal mode proper to law and religion, which both have a performative character.

\footnotetext{
${ }^{22}$ Agamben, Kingdom and Glory, 279.

${ }^{23}$ Agamben, Remnants of Auschwitz, 52.

${ }^{24}$ See especially Agamben, The Open, 22; Agamben, Homo Sacer, 89-91.

${ }^{25}$ Agamben, Homo Sacer, 89.

${ }^{26}$ Agamben, Homo Sacer, 91.

27 Agamben, Homo Sacer, 91.

${ }^{28}$ Agamben, Creation and Anarchy, 59.

${ }^{29}$ Agamben, Creation and Anarchy, 59.

${ }^{30}$ Agamben, Creation and Anarchy, 59.

${ }^{31}$ Agamben, Sacrament of Language, 57-58.

${ }^{32}$ Agamben, Sacrament of Language, 61.

${ }^{33}$ Agamben, Creation and Anarchy, 59.
} 
This is to say that words and phrases in those discourses do not refer to being, but to having to be. ${ }^{34}$ This division corresponds to experiments at the junction of power-knowledge in that the scientific knowledge is based on the indicative mood, whereas the power exercised over the subjects is in the imperative mood. However, the next section shows that the mere mutual inclusion to the same species in a biological and scientific sense is a necessary but not sufficient element of unlawful human experimentation. It must also be accompanied by a sense of being excluded in some way from the general group to which the experimenter sees themself as belonging. The deep irony here is that the common biological humanity of the experimental subjects with the experimenters was necessary for the experiment's usefulness, but that commonality was effaced by the racial and political dehumanisation of the subjects to make the experiments possible and palatable on those human subjects. Thus, the victims were biologically human but considered as subhuman through racial and class-based distinctions, which is to say political and not biological justifications without which the atrocious experiments would not have occurred.

\section{Discrimination as a Core Element of Unlawful Experiments}

International criminal law provides two examples of convictions for unlawful human experimentation that occurred in Nazi Germany and Pol Pot's Cambodia, both of which were based on discrimination of race and class, respectively. To start with the instance prior in time, although he was never tried, Dr Sigmund Rascher's (spelt Roscher by Agamben) name is everywhere in the Medical Case conducted under Control Council Law No. 10 at the Nuremberg Military Tribunals-and with good reason. The experiments were Dr Rascher's brainchild and he would have been tried had he not already met his death, ironically enough in a concentration camp. ${ }^{35}$ Agamben analysed this case among other examples in Homo Sacer and made three theses regarding 'bare life': 36

1. The original political relation is the ban (the state of exception as zone of indistinction between outside and inside, exclusion and inclusion).

2. The fundamental activity of sovereign power is the production of bare life as originary political element and as threshold of articulation between nature and culture, zoe and bios.

3. Today it is not the city but rather the camp that is the fundamental biopolitical paradigm of the West.

In that case tellingly supportive of Agamben's bare life theses, both the prosecution ${ }^{37}$ and the judges cited the instance of an inmate brought in for experimentation 'whose hair and eyes and figure were pleasing to Dr Rascher,' but omit not only precisely what was pleasing about her hair, eyes and figure and why it was pleasing, but also that she was actually spared experimentation as a result. ${ }^{38}$ Dr Rascher himself was not so coy, as his letter partially reproduced below makes plain. He put his feelings over and above the scientific value of the experiment were he to proceed with it:

It hurts my racial feelings to expose to racially inferior concentration camp elements a girl as a prostitute who has the appearance of a pure Nordic and who could perhaps by assignment of proper work be put on the right road.

Therefore, I refused to use this girl for my experimental purposes and gave the adequate reports to the camp commander and the adjutant of the Reich Leader SS. ${ }^{39}$

The second example occurred on 16 November 2018. Judges Nil Nonn (President), Jean-Marc Lavergne, Ya Sokhan, Claudia Fenz and You Ottara of the Trial Chamber of the Extraordinary Chambers in the Courts of Cambodia (ECCC) handed down their unanimous decision in the judgement of Case 002/02 against Nuon Chea and Khieu Samphan, convicting them of crimes against humanity, grave breaches of the Geneva Conventions and genocide. This case is important for at least one compelling reason. Not only was it the third ever international criminal trial for unlawful experimentation, but also it was only the second ever conviction and so warrants attention. In convicting the accused of murder as a crime against humanity the judges also incorporated unlawful experimentation among the unlawful acts, making up that offence as opposed to a standalone offence in its own right. ${ }^{40}$ Indeed, the Trial Chamber was 'satisfied that the Medical Case can be considered as one of several authorities for attributing criminal responsibility for intentional killing even if the perpetrator acted with less than direct intent. ${ }^{41}$ The Trial

\footnotetext{
${ }^{34}$ Agamben, Opus Dei, 84, 119-120.

${ }^{35}$ International Military Tribunal, United States v Karl Brandt, et al. (Case No. 1), 38.

${ }^{36}$ Agamben, Homo Sacer, 92.

${ }^{37}$ International Military Tribunals, United States v Karl Brandt, et al. (Case No. 1), 45.

${ }^{38}$ International Military Tribunals, United States v Karl Brandt, et al. (Case No. 1), 71, 203.

${ }^{39}$ International Military Tribunals, United States $v$ Karl Brandt, et al. (Case No.1), 245.

${ }^{40}$ Co-Prosecutors $v$ Nuon Chea and Khieu Samphan (Extraordinary Chambers in the Courts of Cambodia, Case File/Dossier No. 002/19-092007/ECCC/TC, 16 November 2008) para 2560, 1296; para 2564, 1298.

${ }^{41}$ Co-Prosecutors v Nuon Chea and Khieu Samphan (Extraordinary Chambers in the Courts of Cambodia, Case File/Dossier No. 002/19-092007/ECCC/TC, 16 November 2008) para 636, 346.
} 
Chamber found that the available evidence established at least one prominent confirmed victim whose high social status led to squabbling among the perpetrators:

\begin{abstract}
With regard to medical experiments, the Chamber notes that the available evidence is scarce and does not allow a comprehensive finding on the scope of the practice, both with respect to its duration and frequency. The Chamber finds, however, that THACH Chea's wife was detained at S-21 and was subjected to an experiment to allow the medical unit to study the surgical process on a live body. She died as a result of this experiment and SON Sen blamed Duch and Nat for allowing this to happen to the wife of a famous person, saying that a normal person's wife should have been taken. ${ }^{42}$
\end{abstract}

This relative lack of value attributed to certain human lives - thereby, ascribing those vulnerable humans as being the proper subject of unlawful experimentation-was not unique to Case 002/02. Indeed, this point of vulnerable populations being an experimental target precisely because they are vulnerable, and neither solely for the good of science nor for the advancement of human knowledge necessarily, was not lost on the ECCC Trial Chamber's consideration of the Medical Case:

The factual analysis of the [Medical] case shows that while the Nazi doctors had a complete disregard for the life of the individuals subjected to their brutal experiments, or even considered the death of many of them as an expected outcome, in some instances their objective was to assess if it was possible to survive extreme conditions or particularly severe disease. In such situations the intent involved taking the risk of endangering the life of those subjected to the experiments, with the knowledge that this would likely cause their death. ${ }^{43}$

However, in the ECCC case the vulnerability was one based on class whereas in the Medical Case the vulnerability was (as shown above) on a racial basis. What is more, although the experimental victims' lack of consent was key to the finding of guilt in the Medical Case, this did not feature explicitly with regard to unlawful experimentation in Case 002/02, even though they looked at consent in the context of forced marriage and enslavement. ${ }^{44}$ To be fair, it was implicit in the legal finding that it was murder as a crime against humanity:

Due to the forced nature of the blood drawing, the fact that these deaths were recorded in S-21 documents, and the nature of the surgical medical experiment, the Chamber finds that the direct perpetrators not only intended to cause serious bodily harm to the victims but acted with the knowledge that the blood drawing and the live surgical experiment could lead to death and accepted such outcome. The fact that the perpetrators repeatedly performed blood drawing and observed the physical effects that the procedure had on the prisoners' bodies and at times their resulting deaths confirms their knowledge and acceptance of the result of their acts. ${ }^{45}$

In any event it is sufficiently clear that both the Medical Case and Case 002/02 had unlawful experimentation only occurring on the basis of power over victims who had been denuded of all legal protections for political reasons.

\title{
The Theodicy of Justifying the Evil Effects and Intent of Power by the Value of the Knowledge to Be Gained
}

In the Medical Case the Tribunal noted the Defence's argument that 'the protagonists of the practice of human experimentation justify their views on the basis that such experiments yield results for the good of society that are unprocurable by other methods or means of study. ${ }^{46}$ Benjamin critiqued the Kantian ${ }^{47}$ ethics that are implicit in this judgement by countering in an allusive footnote that 'one might, rather, doubt whether this famous demand does not contain too little - that is, whether it is permissible to use, or allow to be used, oneself or another in any respect as a means. Very good grounds for such doubt could be adduced. ${ }^{48}$ In the same place Benjamin specifies language as a 'sphere of human agreement that is nonviolent to the extent that it is wholly inaccessible to violence,' but laments that this 'sphere of human agreement' has been 'penetrated by legal violence in the penalty placed on fraud. ${ }^{49}$

\footnotetext{
${ }^{42}$ Co-Prosecutors v Nuon Chea and Khieu Samphan (Extraordinary Chambers in the Courts of Cambodia, Case File/Dossier No. 002/19-092007/ECCC/TC, 16 November 2008) para 2447, 1233-1234.

${ }^{43}$ Co-Prosecutors v Nuon Chea and Khieu Samphan (Extraordinary Chambers in the Courts of Cambodia, Case File/Dossier No. 002/19-092007/ECCC/TC, 16 November 2008) para 636, 345.

${ }^{44}$ Co-Prosecutors v Nuon Chea and Khieu Samphan (Extraordinary Chambers in the Courts of Cambodia, Case File/Dossier No. 002/19-092007/ECCC/TC, 16 November 2008) para 267, 125; para 664, 356, respectively.

${ }^{45}$ Co-Prosecutors $v$ Nuon Chea and Khieu Samphan (Extraordinary Chambers in the Courts of Cambodia, Case File/Dossier No. 002/19-092007/ECCC/TC, 16 November 2008) para 2565, 1298.

${ }^{46}$ International Military Tribunals, Trials of War Criminals, 181.

${ }^{47}$ Kant, Practical Philosophy, 429.

${ }^{48}$ Benjamin, "Critique of Violence," 285.

${ }^{49}$ Benjamin, "Critique of Violence," 289.
} 
However, the Tribunal opposed that approach by the Defence with the imperative 'that certain basic principles must be observed to satisfy moral, ethical and legal concepts. ${ }^{50}$ The first and by far most fully articulated of these was that "the voluntary consent of the human subject is absolutely essential. ${ }^{51}$ This imposed a 'personal' non-delegable 'duty and responsibility for ascertaining the quality of the consent' resting 'upon each individual who initiates, directs or engages in the experiment. ${ }^{52}$ However, quality of consent notwithstanding, consent as such was deemed to not be a defence against charges of wounding and inflicting bodily harm in $R v$ Brown.${ }^{53}$ Not only that but the legal notion of consent of victims is more or less superfluous to the scientific efficacy of experimentation conducted upon them. It needs noting that not all but only 'unnecessary physical and mental suffering and injury' were prohibited. ${ }^{54}$ The Defence were not alone in justifying the atrocious experiments by recalling their good results as well as by invoking their necessity. For example, nerve surgeon Dr Susan Mackinnon is quoted as saying 'she feels uncomfortable with its [Eduard Pernkopf's book of anatomy] origin, but using the book is a crucial part of being an "ethical surgeon" - and that she could not do her job without it. ${ }^{55}$ Along with that the BBC reported that "Rabbi Joseph Polak-a Holocaust survivor and professor of health law-believes the book is a "moral enigma" because it is derived from "real evil, but can be used in the service of good"., 56

These justifications are ethically kin to Mephistopheles's self-description in Johann Wolfgang von Goethe's Faust as:

a part of that force

which, always willing evil, always produces good. ${ }^{57}$

This is neither the sole Faustian referent here. Agamben's analysis of bare life is always heavily reliant on Foucault, whom Agamben follows to show how society crosses over the threshold into 'biological modernity,' where the life of the human species and individual become what is at stake in political calculation. This is to say health and biological life become a problem of sovereign power. In a crucial passage Agamben directly quotes Foucault:

What follows is a kind of bestialization of man achieved through the most sophisticated political techniques. For the first time in history, the possibilities of the social sciences are made known, and at once it becomes possible both to protect life and to authorize a holocaust..$^{58}$

That passage is simply too redolent of Faust to be coincidental, as this dialogue that Goethe puts in the mouth of Mephistopheles would indicate:

I merely see how mankind toils and moils

Earth's little god's still do not change a bit,

are just as odd as on their primal day.

Their lives would be a little easier if

You'd not let them glimpse the light of heaven-

they call it Reason and employ it only

to be more bestial than any beast. ${ }^{59}$

To further belabour this point, Foucault himself described the articulation of power-knowledge as a 'Faustian pact' 'to exchange life in its entirety for sex itself,' and that 'one would have to speak of bio-power to designate what brought life and its mechanisms into the realm of explicit calculations and made knowledge-power an agent of transformation of human life. ${ }^{60}$ Foucault notes too how the experiment through power-knowledge successfully combines examination with the ceremonial of power and production of truth:

The examination combines the techniques of an observing hierarchy and those of a normalizing judgement. It is a normalizing gaze, a surveillance that makes it possible to qualify, to classify and to punish. It establishes over individuals a visibility through which one differentiates them and judges them. That is why, in all the mechanisms of discipline, the examination is highly ritualized. In it are combined the ceremony of power and the form of the experiment, the deployment of force and the

\footnotetext{
${ }^{50}$ International Military Tribunals, Trials of War Criminals, 181.

${ }^{51}$ International Military Tribunals, Trials of War Criminals, 181.

${ }^{52}$ International Military Tribunals, Trials of War Criminals, 182.

53 [1993] UKHL 19, [1994] 1 AC 212.

${ }^{54}$ International Military Tribunals, Trials of War Criminals, 182

${ }^{55}$ Baker, "Nazi Book," para 9.

${ }^{56}$ Baker, "Nazi Book," para 10.

${ }^{57}$ Goethe, Faust, lines 1335-1336.

${ }^{58}$ Agamben, Homo Sacer, 10.

${ }^{59}$ Goethe, Faust, lines 280-286.

${ }^{60}$ Foucault, History of Sexuality, 143.
} 
establishment of truth. At the heart of the procedures of discipline, it manifests the subjection of those who are perceived as objects and the objectification of those who are subjected. The superimposition of the power relations and knowledge relations assumes in the examination all its visible brilliance. It is yet another innovation of the classical age that the historians of science have left unexplored. ${ }^{61}$

Indeed, Faust prior to making the pact that bears his name is among others already unusually steeped in learning medicine. In his own words:

I've studied now, to my regret,
Philosophy, Law, Medicine,
and-what is worst-Theology
from end to end with diligence. ${ }^{62}$

Further, Faust like his father before him was a medical experimenter, as the following dialogue illustrates:

OLD PEASANT. It is indeed appropriate

that on this festive day you come among us;

as well we know, when times were bad

you always were disposed to help us!

Many a man is here alive

who, at the time your father stopped the plague,

was snatched by him at the last moment

from the burning frenzy of his fever.

You too-you were a young man then-

would enter every stricken house

and yet, although they carried off so many corpses,

you always would come out unharmed,

surviving every trial and test-

by the Helper above our helper was helped.

VILLAGERS. Good health to one who's tried and true,

and may he be our help for many years to come!

FAUST. Offer your homage to the Helper above

Who teaches that we all should help each other. ${ }^{63}$

This is not the only medical experimentation theme in Faust. Goethe even paraphrases Hippocrates, saying:

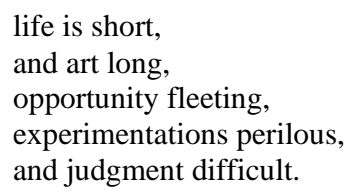

into:

WAGNER. Alas, that art is long,

and human life so short! ${ }^{64}$

Astonishingly, not only do we find Paracelsus cited by the Defence in the Medical Case at Nuremberg, ${ }^{65}$ but also Paracelsus provided Goethe with source material for Faust. ${ }^{66}$ It is astonishing because, as Binswanger and Smith writing in the Bulletin of the World Health Organization note of Paracelsus:

'we shall be like Gods.' ... 'Natural magic will make it possible to see beyond the mountains, to divine the future, to cure all diseases, to make gold, and even to duplicate God's greatest miracle - the creation of man himself.' ... Many would argue that

\footnotetext{
${ }^{61}$ Foucault, Discipline and Punish, 184-185.

${ }^{62}$ Goethe, Faust, lines 354-357.

${ }^{63}$ Goethe, Faust, lines $993-1010$

${ }^{64}$ Goethe, Faust, lines 558-559, 1010.

${ }^{65}$ International Military Tribunals, United States v Karl Brandt, et al. (Case No. 1), 75-77.

${ }^{66}$ Smith, "Scientific Themes," 197-198.
} 
science has either achieved or will soon achieve most of these things in one way or another, but some would also worry about what Faustian wagers are made in the process. ${ }^{67}$

Like Faust Goethe too was a scientist. ${ }^{68}$ As Thomas Huxley noted in the very first article for Nature, 'in 1786, [Goethe] gave himself incredible trouble to get other people to take an interest in his discovery, that man has a intermaxillary bone. ${ }^{69}$ Goethe went through the trouble to oppose his contemporaries who argued the opposite to distinguish and separate humans from the animal kingdom. ${ }^{70}$ This theological defence of human separateness and superiority to other animals is what Goethe sought to refute through scientific demonstration..$^{71}$ In that way his contribution was to the definition of humanity as a species as opposed to humanity as a norm or standard of conduct synonymous with 'humaneness.' International criminal law does combine both of these poles in The Rome Statute for the International Criminal Court, which refers to 'humanity' in only two contexts. ${ }^{72}$ The first is in the preamble speaking of 'unimaginable atrocities that deeply shock the conscience of humanity,' referencing humanity as a standard or norm. The second is always within the context of crimes against humanity in Articles 5 and 7 , referencing humanity as a group as well as a norm intended to protect distinct human populations. Here, humanity, therefore, references not only a biological species - Homo sapiens - that is distinguished from the rest of the zoological kingdom by selfawareness, but also the conduct expected of individual members of that species. Christopher McLeod refers to these as humankind and human nature, respectively. ${ }^{73}$ 'Humanity' then is inevitably punned, consciously or not, in international criminal law. Agamben argues that man [sic] is 'a field of dialectical tensions' separating 'animality and the humanity,' which takes bodily form in it. ${ }^{74}$ This 'means that man is the being which recognises itself as such, that man is the animal that must recognize itself as human to be human. ${ }^{75}$ In that way, for international criminal law, humanity as a term occupies a junction between norm and value, or law and fact.

Although the International Committee of the Red Cross's 2016 Commentary on the 1st Geneva Convention of $1949^{76}$ notes the relevance of the International Ethical Guidelines For Epidemiological Studies ${ }^{77}$ and the International Ethical Guidelines for Biomedical Research Involving Human Subjects ${ }^{78}$ for the justification of human experiments, none of these instruments mention criminal culpability at all—not even the World Medical Association's Declaration of Helsinki. ${ }^{79}$ Therefore, this leaves only the Medical Case and Case 002/02 as the extant exemplars of the law grappling with this difficult area in which medical ethics may supplement but cannot supplant international criminal law.

\section{Conclusion}

This paper began by locating human experimentation at the intersection of the Foucauldian power-knowledge axis, specifically as it has been developed in Agamben's work, where humans are equally both examining subjects and examined objects in terms of species but completely unequally in terms of valorisation of life. It went on to identify how discrimination, especially on the basis of race and class, has played a key role in the selection of human experimental subjects, before demonstrating that the justifications for experimentation along the power-knowledge axis are often theodicean in justifying the evil effects and intent of power by the promise of the knowledge to be gained. It took that political theodicy as an opportunity to then read the Faustian pact narrative as already ubiquitous in human experimentation and illustrate that ubiquity both textually and thematically. This analysis indicated that if experiments were solely based within a scientific paradigm — and clearly they are not—-they would not be so legally and politically charged with discriminatory practices. What needs more critical reflection is the political theodicy of arguing that the power exercised over experimental subjects (in reality humans as objects) is justifiable by the knowledge thereby sought to be gained.

\footnotetext{
${ }^{67}$ Binswanger, "Paracelsus and Goethe," 1163.

${ }^{68}$ Goethe, Scientific Studies, 111-116.

${ }^{69}$ Huxley, Aphorisms by Goethe, 10 .

70 Wells, "Intermaxillary Bone," 350.

${ }^{71}$ Preece, Vivisection, 411.

${ }^{72}$ Rome Statute of the International Criminal Court, opened for signature 17 July 1998, 2187 UNTS 90, UN Doc A/CONF.183/9 (entered into force 1 July 2002) preamble and arts 5, 7.

${ }^{73}$ Macleod, "Crimes against Humanity," 283.

${ }^{74}$ Agamben, The Open, 12.

75 Agamben, The Open, 26.

${ }^{76}$ Blanc, Commentary of 2016, art 50.

${ }^{77}$ Council for International Organizations of Medical Sciences, International Ethical Guidelines.

${ }^{78}$ Council for International Organizations of Medical Sciences, International Ethical Guidelines.

79 World Medical Association, "Declaration of Helsinki."
} 


\section{Acknowledgements}

A debt of gratitude is owed to the other co-Editors of the Special Issue Symposium: What is Real about Law and Technology? Kieran Tranter and Charles Lawson and the outstanding anonymous reviewer, as well as Wouter Werner, Peter Rush, Frédéric Mégret, Tim Peters, and Kanyiri Kariuki, for their thoughtful comments on earlier iterations of this article.

\section{Bibliography}

Agamben, Giorgio. Creation and Anarchy: The Work of Art and the Religion of Capitalism, translated by Adam Kotsko. Stanford: Stanford University Press, 2018.

- Karman: A Brief Treatise on Action, Guilt, and Gesture, translated by Adam Kotsko. Stanford: Stanford University Press, 2018.

- Homo Sacer: Sovereign Power and Bare Life, translated by Daniel Heller-Roazen. Stanford: Stanford University Press, 1998.

- Means without End: Notes on Politics, translated by Cesare Casarino and Vincenzo Binetti. Minnesota: University of Minnesota Press, 2000.

- Opus Dei: An Archaeology of Duty, translated by Adam Kotsko. Stanford: Stanford University Press, 2013. 1999.

- The Kingdom and the Glory for a Theological Genealogy of Economy and Government, translated by Lorenzo

Chiesa (with Matteo Mandarini). Stanford: Stanford University Press, 2011.

. The Open: Man and Animal, translated by Kevin Attel. Stanford: Stanford University Press, 2003.

. The Sacrament of Language: An Archaeology of the Oath (Homo Sacer II, 3), translated by Adam Kotsko. Stanford: Stanford University Press, 2011.

. The Signature of All Things: On Method, translated by Luca D'Isanto (with Kevin Atell). New York: Zone Books, 2009.

- The Use of Bodies, translated by Adam Kotsko. Stanford: Stanford University Press, 2016.

What Is Real, translated by Lorenzo Chiesa. Stanford: Stanford University Press, 2018.

. Infancy and History: Essays on the Destruction of Experience, translated by Liz Heron. London and New York: Verso, 1993

- Potentialities: Collected Essays in Philosophy, translated by Daniel Heller-Roazen. Stanford: Stanford University Press, 1999.

Aurey, Xavier. “The Nuremberg Doctors' Trial: Looking Back 70 Years Later.” International Criminal Law Review 17, no 6 (2017): 1049-1069. https://doi.org/10.1163/15718123-01706004.

Baker, Keiligh. "Eduard Pernkopf: The Nazi Book of Anatomy Still Used by Surgeons.” BBC News, August 18, 2019. https://www.bbc.com/news/amp/health-49294861?_twitter_impression=true.

Benjamin, Walter. "Critique of Violence." In Reflections: Essays, Aphorisms, Autobiographical Writings, translated by Edmund Jephcott and edited by Peter Demetz, 277-300. New York: Schocken Books, 1986.

Binswanger, Hans C. and Kirk R. Smith. "Paracelsus and Goethe: Founding Fathers of Environmental Health Public Health Classics." Bulletin of the World Health Organization 78, no 9 (2000): 1162-1164.

Blance, Valéry and Florent Isselin. Commentary of 2016: Convention (I) for the Amelioration of the Condition of the Wounded and Sick in Armed Forces in the Field. Geneva, 12 August 1949. Geneva: International Committee of the Red Cross, 2016

Control Council Law No. 10. "Punishment of Persons Guilty of War Crimes, Crimes against Peace and against Humanity, 20 December 1945." Official Gazette of the Control Council for Germany, no 3 (31 January 1946): 50-55.

Council for International Organizations of Medical Sciences. International Ethical Guidelines for Biomedical Research Involving Human Subjects. Geneva: CIOMS, 2002.

Council for International Organizations of Medical Sciences and World Health Organization. International Ethical Guidelines for Epidemiological Studies. Geneva: CIOMS, 2009.

Foucault, Michel. Aesthetics, Method, and Epistemology, translated by Robert Hurley and others. Volume 2. New York: The New Press, 1998.

- Discipline and Punish: The Birth of the Prison, translated by Alan Sheridan. New York: Vintage, 1977.

- Politics, Philosophy Culture: Interviews and Other Writings 1977-1984, translated by Alan Sheridan. New York: Routledge, 1988.

. The History of Sexuality Volume I: An Introduction, translated by Robert Hurley. New York: Pantheon, 1978.

. The Politics of Truth, translated by Lysa Hochroth and Catherine Porter. Los Angeles: Semiotext(e), 2007. 
Goethe, Johann Wolfgang von. Faust I \& II, Volume 2: Goethe's Collected Works-Updated Edition (Princeton Classics, Book 108). Princeton: Princeton University Press, 2014.

. Scientific Studies, edited and translated by Douglas Miller. New York: Suhrkamp Publishers, 1988.

Huxley, Thomas. "Nature: Aphorisms by Goethe." Nature 1 (1869): 9-11. https://doi.org/10.1038/001009a0.

International Military Tribunal. Trials of War Criminals Before the Nuernberg Military Tribunals Under Control Council Law No. 10, Nuernberg, October 1946-April 1949. Volumes I-II. Washington, D.C.: United States Government Printing Office.

. United States of America v Karl Brandt, et al. (Case No. 1). In Trials of War Criminals Before the Nuernberg Military Tribunals Under Control Council Law No. 10, Nuernberg, October 1946-April 1949. Volumes I-II. Washington, D.C.: United States Government Printing Office.

Kant, Immanuel. Practical Philosophy, translated by Mary J. Gregor. Cambridge: Cambridge University Press, 1996.

Kotsko, Adam. Agamben's Philosophical Trajectory. Edinburgh: Edinburgh University Press, 2020.

Lengyel, Olga. Five Chimneys: A Woman Survivor's True Story of Auschwitz. Chicago: Academy Chicago Publishers, 1995.

Macleod, Christopher. "Towards a Philosophical Account of Crimes against Humanity." European Journal of International Law 21, no 2 (2010): 281-302. https://doi.org/10.1093/ejil/chq031.

Preece, Rod. "Darwinism, Christianity, and the Great Vivisection Debate." Journal of the History of Ideas 64, no 3 (2003): 399-419. https://doi.org/10.2307/3654233.

Redfern, Walter D. Puns. Oxford: Blackwell, 1985.

Smith, Peter D. "Was die Welt im Innersten zusammenhalt": Scientific Themes in Goethe's Faust. In A Companion to Goethe's Faust: Parts I and II, edited by Paul Bishop. New York: Camden House, 2006.

Wells, George A. "Goethe and the Intermaxillary Bone." The British Journal for the History of Science 3, no 4 (1967): 348361. https://doi.org/10.1017/S0007087400002910.

World Medical Association. "Declaration of Helsinki: Ethical Principles for Medical Research Involving Human Subjects." Bulletin of the World Health Organization 79, no 4 (2001): 373-374.

\section{Primary Legal Material}

Co-Prosecutors $v$ Nuon Chea and Khieu Samphan (Extraordinary Chambers in the Courts of Cambodia, Case File/Dossier No. 002/19-09-2007/ECCC/TC, 16 November 2008).

$R v$ Brown [1993] UKHL 19, [1994] 1 AC 212.

Rome Statute of the International Criminal Court, opened for signature 17 July 1998, 2187 UNTS 90, UN Doc A/CONF.183/9 (entered into force 1 July 2002). 